\title{
Liberation Theology: problematizing the historical projects of democracy and human rights
}

\author{
Teologia da Libertação: problematizando os projetos \\ históricos da democracia e dos direitos humanos
}

\section{Teología de la liberación: problematizando los proyectos históricos de democracia y derechos humanos}

\author{
(iD) Graham McGeorch \\ Faculdade Unida, Vitória, Espírito Santo, Brasil \\ graham@faculdadeunida.com.br
}

\begin{abstract}
Liberation Theology and Liberation Christianity continue to inspire social movements across Latin America. Following Michael Lowy's analytical and historical distinction between Liberation Christianity (emerging in the 1950s) and Liberation Theology (emerging in the 1970s), this paper seeks to problematize the historical projects of democracy and human rights, particularly in relation to the praxis of Liberation Christianity and the reflection of Liberation Theology. Liberation Theology emerged across Latin America during a period of dictatorship and called for liberation. It had neither democracy nor human rights as its central historical project, but rather liberation. Furthermore, Liberation Christianity, which includes the legacy of Camilo Torres, now seeks to 'defend democracy' and 'uphold human rights' in its ongoing struggles despite the fact that the democratic project has clearly failed the majority of Latin Americans. Both redemocratization and 'pink tide' governments were not driven by liberation. At the beginning of the first Workers' Party government in Brazil, Frei Betto - a leading liberation theologian - famously quipped 'we have won an election, not made a revolution'. In dialogue with Ivan Petrella, this article suggests that Liberation Theology
\end{abstract}


needs to 'go beyond' broad narratives of democracy and human rights to re-establish a historical project of liberation linked to what the Brazilian philosopher, Roberto Mangabeira Unger, calls institutional imagination.

Keywords: Liberation theology. Liberation christianity. Democracy. Human Rights. Institutional imagination.

Resumo: A teologia da libertação e o cristianismo de libertação continuam a inspirar movimentos sociais na América Latina. Seguindo a distinção analítica e histórica de Michael Lowy entre cristianismo de libertação (surgido na década de 1950) e a teologia da libertação (surgida na década de 1970), este artigo busca problematizar os projetos históricos de democracia e direitos humanos em relação à práxis do cristianismo de libertação e à reflexão da teologia da libertação. A teologia da libertação emergiu na América Latina durante o período das ditaduras e clamou por libertação. Nem a democracia, nem os direitos humanos foram seu projeto histórico central, mas sim a libertação. Ademais, o cristianismo de libertação, que inclui o legado de Camilo Torres, agora busca 'defender a democracia' e 'apoiar direitos humanos' nas suas lutas contemporâneas, apesar do fato de o projeto democrático claramente ter decepcionado a maioria dos latino-americanos. Tanto a redemocratização como as "ondas de governos rosas" não foram direcionadas para a libertação. No início do primeiro governo do Partido dos Trabalhadores no Brasil, Frei Betto - um influente teólogo da libertação - disse 'ganhamos uma eleição, não fizemos uma revolução'. Em diálogo com Ivan Petrella, este artigo sugere que a teologia da libertação precisa 'ir além' das grandes narrativas de democracia e direitos humanos para restabelecer um projeto histórico de libertação ligado à ideia de 'imaginação institucional' do filósofo brasileiro, Roberto Mangabeira Unger.

Palavras-chaves: Teologia da libertação. Cristianismo de libertação. Democracia. Direitos Humanos. Imaginação institucional.

Resumen: La teología de la liberación y el cristianismo de la liberación aún inspiran movimientos sociales en América Latina. Siguiendo la distinción analítica e histórica de Michael Lowy entre el cristianismo de liberación (emergente en 1950) y la teología de la liberación (que surgió en la década de 1970), este artículo busca problematizar los proyectos históricos de 
democracia y derechos humanos en relación con la praxis de la liberación del cristianismo y la reflexión de la liberación. La teología de la liberación surgió en América Latina durante la dictadura y clamaba por liberación. Ni la democracia ni los derechos humanos fueron su proyecto histórico central, sino la liberación. Además, el cristianismo de liberación, que incluye el legado de Camilo Torres, ahora busca 'defender la democracia' y 'apoyar los derechos humanos' en sus luchas contemporáneas a pesar de que el proyecto democrático claramente ha decepcionado la mayoría de los latinoamericanos. Tanto la redemocratización como los 'gobiernos rosados' no fueron impulsados por la liberación. Al comienzo del primer gobierno del Partido de los Trabajadores en Brasil, Frei Betto, un influyente teólogo de la liberación, dijo "ganamos una elección, no hicimos una revolución". En diálogo con Ivan Petrella, este artículo sugiere que la teología de la liberación necesita 'ir más allá' de las grandes narrativas de democracia y derechos humanos para restablecer un proyecto de liberación histórico vinculado a la idea de 'imaginación institucional' del filósofo brasileño Roberto Mangabeira Unger.

Palabras-clave: Teología de la liberación. Cristianismo de la liberación. Democracia. Derechos humanos. Imaginación institucional.

Data de recebimento: 31/07/2019

Data de aceite: 01/11/2019 
Liberation Theology: problematizing the historical projects of democracy...

\section{A Proposal I}

The nature and mission of theology is regime change. It is worth stating this hypothesis at the outset because theology, and particularly Liberation Theology, has become many things since Gustavo Gutierrez's seminal publication in 1971, Teología de la Liberación. Luis Martinez Andrade and Thia Cooper are two scholars who have documented the many things that Liberation Theology has become in the intervening period.

Luis Martinez Andrade has noted the various tendencies within Liberation Theology, documenting different (although not necessarily exclusive) groupings and influences in his books, Religion without Redemption (2015) and Ecología y Teología de la Liberación (2019). Andrade points to the influence of a European theological formation on the early Liberation Theologians, and the contribution of Europeans to a specifically Latin American pastoral and theological approach. In this he includes people like Gustavo Gutierrez, Juan Luis Segundo, Franz Hinkelammert and Jose Comblin (amongst others) who either studied in Europe or are themselves European (ANDRADE, 2019, p. 30). He also notes the importance of the work of Marxist theorists like Ernst Bloch, Jose Mariátegui and Walter Benjamin and in particular highlights the critiques of those associated with the Departamento Ecumenico de Investigaciones (DEI) in Costa Rica who developed a critique of capitalism as religion (such as Pablo Richard and Jung Mo Sung) (ANDRADE, 2015, p. 104).

Another important grouping is associated with Enrique Dussel and the philosophy of liberation and the critiques of modernity and the coloniality of power. Andrade extends his analysis to include themes like ecology (Leonardo Boff), gender and sexuality (Marcella Althaus-Reid) and, I would add, inter-religious dialogue (Mario Aguilar) within this framework of a critique of modernity and the coloniality of power. 
Liberation Theology: problematizing the historical projects of democracy...

Andrade's approach to the problem is Latin American. His understanding of Liberation Theology is restricted to Latin America or those associated with Latin America. Thia Cooper (2013) in her work has introduced a transnational perspective to the varied nature of Liberation Theology in the collected work, The Reemergence of Liberation Theology. Cooper's approach draws in more themes than Andrade. She notes:

Liberation theologies have been active in many contexts, although ignored in the academy and many churches. Theologies of liberation expanded out from the Latin American liberation theology of the Catholic Church to other forms of Christianity, and liberation theologies have emerged in other religious traditions. They address economic and political poverty, as well as gender inequality, racial inequality, sexual inequality, and so forth. This struggling occurs in a variety of settings around the world. (COOPER, 2013, p. 3).

Her collected work has contributions from liberation theologians from India, Palestine and Latin America, although the focus is more weighted towards Latino/a and Black contributions from the US. These two approaches from Andrade and Cooper underline Liberation Theology's diversity today.

The diversity that is documented by Andrade and Cooper resists being contained by Michael Lowy's analytical and historical distinction between Liberation Christianity (emerging in the 1950s) and Liberation Theology (emerging in the 1970s). However, Lowy's proposal does draw into sharp focus the relationship between Liberation Christianity, Liberation Theology and the historical projects of democracy and human rights in Latin America. It is in Liberation Christianity, and certainly that espoused by Camilo Torres, the Cuban Revolution, the Sandinistas and Zapatistas, that one finds the seeds of the proposal that the nature and mission of theology is regime change. 
Liberation Theology: problematizing the historical projects of democracy... Graham McGeorch

\section{A story}

Perhaps to contextualize (and concretize) this theological proposal, I can offer a story from January 2019.

At the conclusion to his Presidential speech at his investiture ceremony, Brazil's current President took a Brazilian flag off the podium and held it aloft with his Vice-President and declared impromptu: "This is our flag and it will never be red. It will only turn red if it needs our blood to keep it green and yellow" (BOLSONARO, 2019). ${ }^{1}$

The crowd roared its approval. A few days later, I was invited to join a meeting of Liberation Christianity. The Pastoral Land Commission (CPT) and Movimento dos Trabalhadores Rurais Sem Terra (MST) held a regional meeting for the states of Rio de Janeiro and Espírito Santo. There were lots of red flags, hats and t-shirts - and no blood! There were also lots of frightened faces amongst those gathered following the Presidential election and the reconfiguration of Brazilian politics. As is customary in meetings of Liberation Christianity, it began with an análise de conjuntura (assessment of context) before opening for group reflections. It quickly struck me how activists were worried by the undermining of democracy throughout the election cycle, and with the proposals of the new government. Equally, it was evident that the ongoing 'judicialization of politics' was seen by activists present at the meeting as a good way to frame the work and struggles of social movements and pastoral agencies in their pursuit of human rights (and indeed land rights). In Brazil's increasingly dysfunctional and polarized politics, the judiciary has entered the vacuum to 'resolve' political disputes and impasses through court rulings. Following this logic, Liberation Christianity - at least in the form of the meeting of the CPT and MST - has highlighted judicial channels - and by implication human rights discourse - as possibly offering political protections for various struggles.

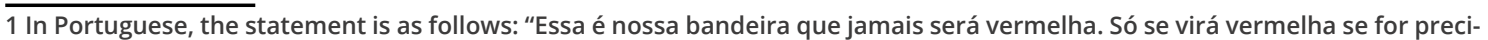
so nosso sangue para mantê-la verde e amarela". 
Liberation Theology: problematizing the historical projects of democracy... Graham McGeorch

Liberation Theology speaks of a theology of liberation and a Christianity of Liberation, not a theology of democracy or a Christianity of human rights. Both of these latter exist, but they are not inspired by the Cuban Revolution. Both of these latter exist, and can even be seen as important tools in the struggle. ${ }^{2}$ However, a Liberation Theology and a Liberation Christianity must 'go beyond' (to take up Ivan Petrella's challenge) and refocus on regime change. For example, at no point in the análise de conjuntura in the Liberation Christianity meeting was recognition of the failure of democracy and human rights for 'the poor' in Brazil discussed.

Ivan Petrella (2006, p. 52) is disposed towards democracy as a method for Liberation Theology. However, he does highlight the need to reject the mainstream definition of democracy. Petrella (2006, p. 52) has traced the relationship between Liberation Theology and democracy to three distinct, but related phases: "democracy via revolutionary socialism, participatory democracy via the base communities, and the current analysis of stagnant democracy. Common to all three phases is Liberation Theology's call for a real democracy which unmasks the capitalist exploitation of the Latin American masses.

Petrella enlists Gustavo Gutierrez and Jose Miguez Bonino to support his view that their revolutionary socialism is a call for real democracy. In the emergence from dictatorships and the failed experiments with Christian Democracy across the continent, Petrella turns to the brothers Boff (Leonardo and Clodovis) and their work with Christian Base Communities (CEBs). Petrella identifies CEBs as a forerunner of popular and participatory democracy. Finally, in Petrella's analysis, along with the stagnation of CEBs comes the stagnation of democracy.

Petrella provides a compelling democratic vision from within Liberation Theology. But it is contestable. Jose Comblin (1996, p. 231) writing at the close of the twentieth century noted:

2 For a fuller discussion of democracy, human rights and the relation to theology see WOLTERSTORFF, Nicholas. Justice, Rights and Wrongs. Princeton: Princeton University Press, 2008 and PAPANIKOLAOU, Aristotle. The Mystical as Political. Notre Dame: University of Notre Dame Press, 2014. 
Liberation Theology: problematizing the historical projects of democracy...

One of the unanimities across Latin America is democracy. Left or Right, everyone unconditionally wants democracy. Democracy has become an unquestionable myth. It is exalted, cultivated, an absolute reference. Behind such enthusiasm is naturally the memory of military regimes and National Security.

When the choice is between dictatorship and democracy, Liberation Theology, naturally, favors democracy. Likewise, while Petrella highlights the work of the Boff brothers with CEBs as a form of popular or participatory democracy, their pastoral work was more focused on the relationship between political parties and Liberation Christianity. Not democracy per se. Clodovis Boff et al. (1987, p. 10) put it this way: "Christians who are active in party politics are trying to articulate in an autonomous manner in order to strengthen the party and to also strengthen faith in this new area of struggle... It is hoped only to open discussion on this subject: what is the current position of Christians in light of party politics today".

The emergence of political parties - in particular the Workers' Party in Brazil - and the relationship of Liberation Christianity to political parties is the focus of the Boff brothers' reflections. There is little reflection about democracy - its nature and its theological roots - in and of itself.

Finally, Jung Mo Sung notes that the armed revolution has been abandoned as a viable option by the Left in Latin America. The only route open is politics. Sung $(2008$, p. 121$)$ calls for profound structural changes and the construction of a new majority that attends to subaltern needs. His proposal, however, depends on demonstrating 'moral superiority' (SUNG, 2008, p. 123) for political positions and advantage without defining what this might look like or be in practice. Petrella (2006, p. 62) is perhaps more honest when he states in his analysis that Liberation Theology has a complex relationship with democracy. It neither rejects it nor fully accepts it as it is practiced in history. 
Liberation Theology: problematizing the historical projects of democracy... Graham McGeorch

In order to 'go beyond', Liberation Theology needs to convince Liberation Christianity that revolutionary change with open utopian horizons is viable. Democracy cannot become stagnant. To place this more concretely, it needs to challenge Liberation Christianity to 'go beyond' democracy and human rights to reflect once again on liberation ${ }^{3}$. Lowy's reflections about the beginnings of Liberation Theology and Liberation Christianity rooted in the 1950 s can shed some light on the necessary steps. To this can be aggregated reflections from Roberto Mangabeira Unger and Ivan Petrella, Boaventura de Sousa Santos's critical reexamination of the role of the Cuban Revolution in leftist projects in the $21^{\text {st }}$ Century, and even Marcella Althaus-Reid's indecent theology.

\section{A proposal II}

As stated at the outset, my working hypothesis is that the nature and mission of theology is regime change. I would like to return to what Michael Lowy has called Liberation Christianity to find the seeds of this proposal of the nature and mission of theology as regime change. Lowy understands Liberation Christianity as both a forerunner to Liberation Theology and the social movement that accompanies Liberation Theology. This is important for what I would like to suggest. I should also state at the outset that I read with and against Lowy.

Lowy posits that Liberation Christianity gains ground in Latin America in the 1960 s as a vast social movement. He suggests that it involves significant sectors of the Latin American church, alongside pastoral and social movements (including Catholic Action, Juventude Universitária Católica (JUC), Juventude Operária Católica (JOC), Comunidades Eclesiais de Base (CEBs)) (LOWY, 2000, p. 56). Lowy (2000, p. 68) also explores some aspects of its development:

\footnotetext{
3 Walter Mignolo notes the closeness and distinction between 'liberation' and 'decolonialism' in his contribution to the collected work, ISASI-DIAZ, Ada Maria; MENDIETA, Eduardo. Decolonizing epistemologies: latino/a theology and philospohy. New York: Fordham University Press, 2012. While aware of Mignolo's suggestion, and the growing literature on decolonial studies, for the purposes of this article the term 'liberation' is maintained when presenting and discussing Liberation Theology and Liberation Christianity, both of which under Mignolo's proposal could be described as 'decolonial theology' and 'decolonial Christianity'.
} 
Liberation Theology: problematizing the historical projects of democracy... Graham McGeorch

firstly, the Roman Catholic church decides to innovate in face of the challenges of the modern world, particularly the rise of Protestantism; secondly, under the influence of leftist sociologists, the people (povo or pueblo in Portuguese and Spanish, to bring out its class aspect missing from the English term) took over the institutions of the Roman Catholic church; thirdly, external and internal convergences on the Roman Catholic church, including World War II, politics of developmentalism in Latin America and the Cuban Revolution. Lowy expands his analysis in the course of his book with regard to the third point.

Lowy begins his book The War of Gods: religion and politics in Latin America (1996) observing that two historic events are fundamental to understanding religion and politics in Latin America since the 1950s: the election of Pope John XXIII and the victory of the Cuban Revolution (LOWY, 2000, p. 7). However, it is my opinion that the book develops around the framework of the importance of Vatican II. In other words, both Liberation Christianity and Liberation Theology are ultimately located by Lowy (and, one might add, by his followers) as participatory and reformist movements in the geopolitics of the Roman Catholic church's reception of Vatican II.

I would like to suggest that rather it is the Cuban Revolution (and revolutionary precursors) that is the primary inspiration for Liberation Christianity and Liberation Theology. Fundamentally, neither Liberation Christianity nor Liberation Theology are primarily focused on reform or renewal of the church. This is a secondary consequence of the primary struggle: regime change. In the analysis of Clodovis Boff and Marcella Althaus-Reid Liberation Christianity and Liberation Theology need to be understood as independent of Church and State. One of the difficulties for both Liberation Christianity and Liberation Theology is that they have become increasingly focused on ecclesiastical matters in detriment to nurturing viable political projects of liberation, in other words of creating conditions for revolution, for regime change.

In a wider sense, the utopian horizon of Liberation Theology has shrunk. Ivan Petrella has argued provocatively that Liberation 
Liberation Theology: problematizing the historical projects of democracy...

Theology has lost sight of viable historical projects of political and economic change (2006). He says this needs to change. This shrinking of the utopian horizon is most clearly demonstrated today by two major trends in Liberation Christianity, particularly evident since the reemergence of democracy in Latin America and the coming (and going) of 'pink tide' governments. Discourse within Liberation Christianity has been widely co-opted into the redemocratisation project and generally expresses itself through human rights discourse and processes. In other words, with Latin America's recent 'turn' (or 'return') to the right, Liberation Christianity has chosen to 'defend democracy' and 'uphold human rights' within the broader narratives of democracy and human rights, without specifying what kind of democracy and human rights it is seeking to defend and uphold, particularly in light of its 'option for the poor'. In the 1950s, these two aspects were secondary to the 'critical reflection on revolutionary praxis'.

To return again to Petrella (2008), in order to counter current trends in scholarship on theologies of liberation and the praxis of Liberation Theology itself, it is necessary to 'go beyond'. By this Petrella means uncovering a more comprehensive and integrated approach to knowledge:

Perhaps the future of liberation theology lies beyond theology.
At the heart of liberation theology lie two elements: the first is
epistemological, the liberationist attempt to do theology from
the standpoint of the oppressed The second is practical/moral,
liberation theology's commitment to thinking about ideas by
thinking about institutions... The epistemological has priority
over the practical/moral: before changing the world you need
to be converted to the need to change the world. (Petrella, 2008,
p. 148).

For those familiar with theologians of liberation, one will find echoes of Juan Luis Segundo. For those familiar with Ivan Petrella, one will find echoes of Roberto Mangabeira Unger. Segundo (1976, 
Liberation Theology: problematizing the historical projects of democracy...

p. 3), a theologian from Uruguay, once remarked: "what will remain of the 'theology of liberation' a few short years?". His question was designed to be positive, to challenge Liberation Theology to consider how to continue to arise from the urgent problems of real life even in the face of academic disdain or accusations of naivety from erudite theology and theologians (SEGUNDO, 1976, p. 5). ${ }^{4} \mathrm{His}$ theological project was above all interested in liberating theology, of going beyond theology, to use Petrella's language. Mangabeira Unger, a Brazilian philosopher, has been used by Petrella and social movements across Latin America to underpin theories of political and social change - particularly those linked to 'institutional imagination' (MANGABEIRA UNGER, 2005). Curiously, as Petrella notes, both Liberation Christianity and Liberation Theology appear largely unfamiliar with Mangabeira Unger:

\begin{abstract}
While the potential use of Roberto Unger's social theory by liberation theology has been acknowledged it has yet to be fully developed. Since Unger's concern lies in the deepening of democracy and the expansion of economic opportunity, this is somewhat surprising, especially given that Unger himself is Brazilian and thus native to a country where liberation theology thrives. Unger has written extensively in the major Brazilian newspapers so ignorance of his work is unlikely. (MANGABEIRA UNGER, 2006, p. 93).
\end{abstract}

Juan Luis Segundo's call to liberate theology and Roberto Mangabeira Unger's call for institutional imagination form the basis for my hypothesis that the nature and mission of theology is regime change. Unger's concept of institutional imagination introduces to politics the possibility of the transitory, even for apparently solidified and eternal concepts like democracy and human rights. Can Liberation Theology and Liberation Christianity imagine a utopian horizon beyond democracy and human rights?

4 It is worth noting that Juan Luis Segundo's 'Liberation Theology' problematises Michael Lowy's categories. Segundo is already publishing a 'Liberation Theology' in the 1960s, and arguably as early as 1948. 


\section{A historical project (for discussion)}

The Chilean liberation theologian Mario Aguilar has suggested: "The end of the military regimes in Latin America and the collapse of the Soviet Union during the early 1990s gave rise to new utopian dreams of a democratic nature in Latin America" (AGUILAR, 2007, p. 1).

According to Aguilar (2007, p. 2), the new utopian dreams of Liberation Theology and Liberation Christianity have been fragmented by the processes of globalization and neocolonialism, alongside the rise of individualism, hedonism and consumerism. This is the positive reading of Liberation Theology's utopian horizon.

Jung Mo Sung, reflecting specifically on Michael Lowy's Liberation Christianity, is altogether more cautious regarding utopian dreams. He introduces us to Nenuca - a religious women who lived in a cortiço in São Paulo in the 1970s (SUNG, 2007, p. 130). Through Nenuca's faith, Sung is able to remind us that Liberation Christianity was not fundamentally about church structures, nor theoretical novelties. Instead: “The 'zero' moment would be the spiritual experience of encountering the person of Jesus in the face of the poor" (SUNG, 2007, p. 130).

Sung uses this 'option for the poor' to demonstrate that the difficulty arises for Liberation Christianity when the God who it claims liberates does not indeed liberate. In other words, the problem described by Sung is that those engaged in Liberation Christianity no longer necessarily encounter the person of Jesus in the face of the poor. Or to put it another way, the question can be asked, who makes an 'option for the poor' in the $21^{\text {st }}$ century and who are 'the poor' for Liberation Christianity? Sung ultimately locates this problem at the door of Liberation Theology as theology. I will return to this in the final (theological) coda.

Sung and Aguilar share a concern for the fragmentation of utopian dreams and spiritual experiences of the encounter with Jesus in the face of the poor. They also share a suspicion of 
Liberation Theology: problematizing the historical projects of democracy... Graham McGeorch

what they call the optimistic affirmations of Liberation Theology. Redemocratisation and the rise of human rights discourse as a historical project of both the Liberation Theology and Liberation Christianity is a case in point.

Democracy and human rights are defended by theologians and social movements alike. Aguilar admits that even by the late 1990s, it was clear that democracy was captive to old localized power structures in Latin America (AGUILAR, 2007). However, neither Liberation Christianity nor Liberation Theology have developed a comprehensive and clear critique of democracy as it is currently practiced, Petrella's preliminary attempts aside. There are fragmented skirmishes. And it is decolonial thinking - and particularly Walter Mignolo's attempt to locate the Zapatistas as a decolonial rather than as a liberation epistemology - that comes closest to integrating different democratic proposals. However, the Zapatistas have not occupied the imaginary space in Liberation Christianity or Liberation Theology in quite the same way as the Cuban Revolution. And Mignolo is not a theologian. This needs to be addressed.

The Cuban Revolution is not primarily about democracy or human rights. It is about regime change. That it is was successful against the odds, in terms of Marxist theories of social change - was crucial to how the left in Latin America received the Revolution. It fitted classic narratives of nuestra America differentiating European and Latin American experiences of reality of revolution. It was also exported.

Boaventura de Sousa Santos (2016) has suggested that Cuba has become a difficult problem for the Left in general, and the Latin American Left in particular. He formulates the problem in the following way: "All modern revolutionary processes are processes of rupture that sit on two pillars: resistance and alternative" (SANTOS, 2016, p. 74). ${ }^{5}$

5 In Portuguese, the statement is as follows: “Todos os processos revolucionários modernos são processos de ruptura que se assentam em dois pilares: a resistência e a alternativa". 
Liberation Theology: problematizing the historical projects of democracy...

According to Santos, due to external pressures Cuba did not find the right balance between resistance and (new) alternatives. Cuba's revolutionary government has been guided by resistance and anything new is a new form of resistance rather than a new solution. The result is a revolutionary process that becomes reformist. The alternative, from a reformist rather than revolutionary perspective, is never a viable option.

Something similar happens to Liberation Theology and Liberation Christianity. From accompanying revolutionary processes - as outlined in the work of Gustavo Gutierrez and Jose Miguez Bonino - there is a turn to reform larger processes like globalization, democracy, human rights. Palavras de Ordem (Words of Order) are 'resist' and 'defend'. This is anomalous when clearly that which is being defended by Liberation Christianity - in this case democracy and human rights - has, at times, oppressed 'the poor' and indeed failed 'the poor' in their quest for liberation. ${ }^{6}$ In other words, there is a defence of abstract theories, such as democracy and human rights, at the expense of practice. For Liberation Theology and Liberation Christianity this is perhaps a 'cardinal $\sin ^{\prime}$ in a theological epistemology that proposes practice first. Moreover, very little energy (publications) is given to alternative viable utopias. Liberation Christianity and Liberation Theology are still largely imprisoned by the Cuban Revolution and have been slow to explore the world of many worlds of the Zapatistas. This in itself hides the power relations within Liberation Christianity and Liberation Theology as Marcella Althaus-Reid has pointed out:

Liberation Theology did not set out chairs for poor women or
poor gays - at least it never did so willingly. The inclusive project
affirmed itself by exclusive policies which determined the identity
of the poor. The poor who were included were conceived of
as male, generally peasant, vaguely indigenous, Christian and

6 Democracy and Human Rights are powerful mobilizing discourses, increasingly used by 'the poor'. However, the theologian Nicholas Wolterstorff has noted that abstract theories need to be rooted in concrete practice otherwise Democracy and Human Rights are 'conferred' to an individual. If Democracy and Human Rights are 'conferred' to the 'poor' the implication is that they can be 'revoked' or 'removed'. In other words, the rights of 'the poor' sit alongside the rights of others in a democracy. This counters Liberation Theology's intuition of a 'preference for the poor'. 
Liberation Theology: problematizing the historical projects of democracy...

heterosexual. In fact militant churches would not have needed many chairs around the table of the Lord if these criteria had been applied. It describes only a minority of the poor. The poor in Latin America cannot be stereotyped so easily and they include urban poor women, transvestites in poor neighbourhoods and gays everywhere. (ALTHAUS-REID, 2007, p. 27).

Even Liberation Theology and Liberation Christianity betray the limits of inclusion.

While Liberation Christianity and Liberation Theology have made use of social theories, I am minded that Sung, Althaus-Reid and Petrella are correct in their analysis that it is the theological nature of liberation that is more problematic for both Liberation Theology and Liberation Christianity. ${ }^{7}$ There is ongoing debate within the Liberation Christianity and Liberation Theology about the adequate use of social theories (which ones to use, for example). Sung is scathing of the stagnation of economic analysis, Althaus-Reid questions the absent themes of gender and sexuality, and Petrella is keen to find an overarching theory that takes account of 'zones of abandonment'. However, to return to Segundo's question posed all those years ago: what will remain of the 'theology of liberation' in a few short years?" (1976, p. 3). Surely neither Liberation Christianity nor Liberation Theology would wish the answer to be, 'our experience of democracy and human rights in Latin America'.

\section{A Theological Coda (for discussion): faith and ideology}

There is no consensus on what is meant by faith; just as there is no consensus on what is meant by ideology. Juan Luis Segundo was among the first theologians of liberation to undertake a

\footnotetext{
7 It is worth stating that there are substantive theological proposals and discussions about the relationship between theology and social sciences. Liberation Theology would do well to enter these dialogues and to heed Ivan Petrella's (2006, p. viii) call to reassess the role of social sciences as a only "pre-theological" moment in its methodology.
} 
Liberation Theology: problematizing the historical projects of democracy...

sustained reflection of Faith and Ideology in his seminal work on Jesus of Nazareth, El Hombre de Hoy ante Jesus de Nazaret (1982). An earlier contribution by Samuel Silva Gotay (1980) drew attention to the fact that Liberation Theology identifies two kinds of ideologies: ideologies of order, and ideologies of change (1980, p. 214). Gotay (1980, p. 214) suggests that Liberation Theology and Liberation Christianity, simply by dividing society into classes identifies a prevailing order that is 'natural', 'reasonable', 'eternal', 'divine' or 'representative', and by implication a critical counter-representation that is to 'delegitimise', 'disintegrate' and 'substitute' this order for another kind of life. Gotay notes that theology, alongside other disciplines, necessarily expresses itself through ideologies.

Juan Luis Segundo advances this argument, too. He suggests that faith and theology without ideology is impossible. However, he goes further than Gotay. While Gotay links ideological expressions to class struggle (a classic Marxist position) positing that the ideologies of order are the domain of the prevailing classes, while ideologies of change pertain to other classes, Segundo is more nuanced indicating that ideologies of order can pertain to 'revolutionary classes' too. Segundo roots the class struggle in dialogue with refracted ideologies of God in different classes. By doing this he is able to highlight that both classes - dominant or ruling and revolutionary - have different conceptions of God but both retain a God with the same performative function. In both classes God's performative function is 'natural', 'reasonable', 'eternal', 'divine' or 'representative', to draw on Gotay's terminology. Is this simply a case of 'false consciousness', to deploy another classic Marxist term? Segundo thinks not. Indeed he argues it is an epistemological problem for Liberation Theology and Liberation Christianity. In other words, how can Liberation Theology and Liberation Christianity 'delegitimise', 'disintegrate' or 'substitute' God or indeed more specifically God's performative function within their ideologies, for without this how can one open viable utopian horizons of change? 
Liberation Theology: problematizing the historical projects of democracy... Graham McGeorch

Segundo's reflections on faith and ideology appear in the 1970s, 1980 s and 1990s in at least three different books - The Liberation of Theology (1976), El hombre de hoy ante Jesus de Nazaret (1982) and El dogma que libera (1989). While in the first two books mentioned Segundo sought to demonstrate the necessity of ideology to faith (and by implication theology), by the time he publishes El dogma que libera, Segundo has suggested that this necessity need not be deterministic. He manages to make this affirmation because, through a pursuit of the liberation of theology, Segundo concludes that dogma (which he understands to be doctrine, theology) is fundamentally unstable. This 'discovery' by Segundo is inherently positive for him and for his understanding of Liberation Theology. It means that theology is not normative, it is evolutionary (Segundo, 2000). In terms of theology, Segundo's discovery is a turn away from the platonic and neo-platonic underpinning of Western theologies (be they Roman Catholic or Protestant) in the ideology of both classes. While a fuller explanation of this is not possible here, it is worth noting again that perhaps Segundo's familiarity with Orthodox theology and particularly Russian Religious Philosophy from his study in France comes to the fore in his turn away from the underpinnings of Western theologies. ${ }^{8}$

The consequences of this are revolutionary. Jose Miguez Bonino $(1975$, p. 2) famously recorded the conversation between performers and congregation at theatre performance by a group of young people from a shanty town in Uruguay in a well-to-do Protestant church: "'Who, then is Jesus Christ?' 'For us' shot back immediately and spontaneously one of the group, 'Jesus Christ is Che Guevara"'.

Bonino's text exposes us to aspects of the class struggle referencing shanty town and well-to-do congregation. It unveils relations of power. The well-to-do congregation ask the questions; the young people from the shanty town respond. And although

\footnotetext{
8 Juan Luis Segundo's doctoral thesis was on the Russian Religious Philosopher Nicholas Berdyaev. It was published in French in 1948, never translated in either Spanish or Portuguese. Odair Pedroso Mateus has written about this 'genesis' of Segundo's theology: MATEUS, Odair Pedroso. Volverán las oscuras golondrinas...: o opúsculo de 1948 e a gênese universitária da obra de J. L. Segundo. In: SOARES, Afonso Maria Ligorio (Ed.). Dialogando com Juan Luis Segundo. São Paulo: Paulinas, 2005. However, I am unaware of any further studies which address the Orthodox influences on the theology of Juan Luis Segundo or indeed other Liberation theologians.
} 
Liberation Theology: problematizing the historical projects of democracy...

Bonino (1975, p. 2) registers the initial shock amongst those who heard the answer, he soon tidies it up by referencing the fact that Jesus has throughout history been associated with the ideal or historical ideology of Christian religion or full humanity. In this case - as Marcella Althaus-Reid would point out - the ideal or historical ideology of Western theology is that Jesus/Che is male, white, heterosexual, and latterly middle class. And herein lies the problem in light of Segundo's reflections on faith and ideology. Jesus as Che Guevara reflects a fixed ideal of a contextualized Jesus. In this, both classes present at the discussion in the church in Uruguay may have different conceptions of Jesus but Jesus has the same performative function.

This is altogether different from the cry Matan a una Marica (They killed a faggot) registered by Marcella Althaus-Reid. The body by the Panamerican Highway is related to the reader through the lens of 'ambiguity' and 'probability' (ALTHAUS-REID, 2004, p. 167): "the body lying in full transvestite regalia, now broken and dirty, as a scene from a cruci/fiction... Who killed her?".

Would those who read the headlines and the story be willing quite so easily to detect the ambiguous body, the transient, transformed, transfigured Jesus? Marcella presents Segundo's 'delegitimised', 'disintegrated' or 'substitute' God in this modern parable. This is one of the places of conflict for ideologies of order and ideologies of change. And it is one that has troubled even Liberation Theology as theology, without reducing it to "pretheology" or social science. In a twist of the classic Marxist position, class perceptions can help structure ideologies and theologies of God. But class alone does not elucidate the ideology of order emanating from the vanguards of Guevara or the necessary determinism of some Liberation Theologies and Liberation Christianity which is so destructive to theories of regime change. In the Marica (faggot) there is no idealized contextualized Jesus. But there is an imaginative horizon of utopian change. 


\section{Conclusion: between loving and voting}

Liberation Theology and Liberation Christianity continue to inspire social movements across Latin America. The movements and the theology which accompanies them are no longer set in dictatorships, although the political regimes may continue to exercise forms of authoritarianism. Democracy and human rights discourses have become, in the words of Jose Comblin (1996, p. 231), "an unquestionable myth". Indeed, the theological status of democracy and human rights has not been fully examined or questioned by Liberation Theology or Liberation Christianity despite the fact that even as early as the late 1990s it was apparent that new democracies in Latin America were captive to old localized power structures (AGUILAR, 2007).

In this paper I have tried to show that Liberation Christianity (emerging in the 1950s) and Liberation Theology (emerging in the 1970s) emerged across Latin America during a period of dictatorship and called for liberation. Neither had democracy or human rights as their central historical project, but rather liberation. The historical projects of both the redemocratization movements and subsequent periods of 'pink tide' governments were not driven by liberation, although they were supported by Liberation Theology and Liberation Christianity.

The crux of the problem for Liberation Theology appears to be its ongoing relationship with the social sciences. The political theories - supported by sociology, economics, amongst others engaged and deployed by Liberation Theology are largely fruits of a the institutional imagination of democratic and human rights utopias. While Petrella has argued boldly, in accord with Roberto Manabeira Unger's social theories of change, of the need for Liberation Theology to 'go beyond' this institutional settlement, he chooses to do so by ultimately challenging Liberation Theology to relocate its epistemologies and methodologies inside the social 
Liberation Theology: problematizing the historical projects of democracy...

sciences and other academic disciplines. This is certainly one option.

However, the 'go beyond', can also be framed as a need for Liberation Theology to further locate its epistemologies and methodologies within theology. An example of this would be to revisit Juan Luis Segundo's proposal to liberate theology. It is clear that democracy is not necessarily a theological concept; although theology can certainly construct arguments in its favor. It is also clear that historical Christianity, while currently favoring democracy, has lived through a myriad of political regimes (and has favored a myriad of political regimes). Liberation Christianity has positioned itself against dictatorship and in favor of democracy, for example.

Moreover, it is even clearer that human rights discourse is not necessarily a theological concept. Indeed the theological based critiques of human rights are quick to highlight that the secular, individuated, autonomous nature of the person developed and defended by human rights discourses before the state and other persons is a limited and limiting perspective of personhood. Frequently theologians arguing for or against human rights discourse find common ground in the theological concept of human dignity. Human rights and human dignity are distinct for theology, independently of whether the latter is used to support or critique the former.

The fact that both Jung Mo Sung and Marcella Althuas-Reid point to the fact that any 'go beyond' suggested by Petrella needs to be theological is perhaps the primary challenge facing Liberation Theology and Liberation Christianity. Without this, Liberation Theology is vulnerable to a reification of democracy and human rights because of its particular relationship with the social sciences. It is worth restating that neither democracy nor human rights are in and of themselves theological concepts. They are human constructs of philosophy and the social sciences, and may or may not be made divine depending on theological options. Clearly Liberation Theology and Liberation Christianity have found and continue to find democracy and human rights to be helpful, 
Liberation Theology: problematizing the historical projects of democracy...

even useful (dare one say divine when so little reflection has been produced by Liberation Theology about democracy and human rights?). However, Liberation Theology has, to this point, supported democracy and human rights because of the analysis of the social sciences. It has been rather slower to analyze democracy and human rights from an 'option for the poor' which demonstrates the widespread failure of both for the Latin American masses. Does this make democracy and human rights a 'pre-theological moment' (PETELLA, 2006, p. viii)?

Petrella suggests that Liberation Theology needs to 'go beyond' broad narratives of democracy and human rights to re-establish a historical project of liberation linked to what the Brazilian philosopher, Roberto Mangabeira Unger, calls institutional imagination. If democracy and human rights, dependent on the analysis from the social sciences is indeed a 'pre-theological moment' does this already place any theology in the 'go beyond' on the horizon of institutional imagination? If the answer is affirmative, as in view of traditional liberal Protestant theology for example, the problem resolves itself relatively simply for Liberation Theology. If the answer is negative, then, as Petrella suggests, there is some theological 'heavy lifting' to be done by Liberation Theology. Liberation Theology and Liberation Christianity are clearly engaged in democratic practices and defence of human rights, often in the face of intolerable injustice and oppression. However, do Liberation Theology and Liberation Christianity love democracy and human rights?

Love is a theological category that has found its way into Liberation Theology and Liberation Christianity. The Cuban Revolution, which provides the primary inspiration for both, brought forth the perspectives of revolutionary action as an act of love. And Liberation Theology - in its indecent and queer turn - has taken this act of love further. Marcella Althaus-Reid (2004, p. 147) has asked what happens when we love those theologically prohibited, when "the institutionalised forms of relations with God are simply not flexible enough"? This love in the 'go beyond' 
Liberation Theology: problematizing the historical projects of democracy...

of the 'institutionalized forms' of theology or (political) society is part of the 'institutional imagination' of Liberation Theology. It is historically grounded - part of what Marcella calls the caminata of theology. It is also the place where Liberation Theology's love of the poor ultimately problemtizes the Augustine edifice of Western theology. This Augustine edifice is found in the theologically seductive categories of a prevailing order that is 'natural', 'reasonable', 'eternal', 'divine' or 'representative', to recall the words of Samuel Gotay. Juan Luis Segundo's attempts to find a critical counter-representation that is 'delegitimising', 'disintegrating' and 'substitutive' of this order for another kind of life - 'institutional imagination' - is the forerunner to Althaus-Reid's critique of the Augustine edifice in Western theology. Loving outside Augustine's theological institution is about more than voting for democracy. This is the challenge to Liberation Theology of the 'go beyond' issued by Petrella.

\section{References}

AGUILAR, Mario. The history and politics of Latin American

Theology. v. I. London: SCM Press, 2007.

AGUILAR, Mario. From feminist theology to indecent theology. London: SCM Press, 2004.

AGUILAR, Mario. Class, sex and the theologian: reflections on the Liberationist Movement in Latin America. In: ALTHAUS-REID, Marcella et al. (Eds.). Another possible world. London: SCM, 2007.

ANDRADE, Luis Martinez. Religion without redemption: social contradictions and awakened dreams in Latin America. London: Pluto Press, 2015. 
Liberation Theology: problematizing the historical projects of democracy...

ANDRADE, Luis Martinez. Ecología y Teología de la Liberación: crítica de la modernidad/colonialidad. Barcelona: Herder, 2019.

BOFF, Clodovis et al. Cristãos: como fazer política. Petrópolis: Vozes, 1987.

BOLSONARO, Jair. Jair Bolsonaro discursa no Palácio do Planalto. Disponível em: http://g1.globo.com/globo-news/jornalglobo-news/videos/t/videos/v/jair-bolsonaro-discursa-no-palaciodo-planalto/7269542/. Acesso em: 27 jun. 2019.

BONINO, Jose Miguez. Doing Theology in a revolutionary situation. Philadelphia: Fortress Press, 1975.

COMBLIN, Jose. Cristãos rumo ao século XXI: nova caminhada de libertação. São Paulo: Paulus, 1996.

COOPER, Thia (Ed). The reemergence of liberation theologies. New York: Palgrave Macmillian, 2013.

GOTAY, Samuel Silva. O pensamento cristão revolucionário na América Latina e no Caribe. São Paulo: Paulinas, 1980.

GUTIERREZ, Gustavo. A Theology of Liberation. London: SCM Press, 2001.

LOWY, Michael. A Guerra dos deuses: religião e política na América Latina. Petrópolis: Vozes, 2000.

MANGABEIRA UNGER, Roberto. Necessidades falsas. São Paulo: Boitempo, 2005.

MATEUS, Odair Pedroso. Volverán las oscuras golondrinas...: o opúsculo de 1948 e a gênese universitária da obra de J. L. Segundo. In: SOARES, Afonso Maria Ligorio (Ed.). Dialogando com Juan Luis Segundo. São Paulo: Paulinas, 2005.

MIGNOLO, Walter. Decolonizing western epistemology/building decolonial epistemologies. In: ISASI-DIAZ, Ada Maria; MENDIETA, Eduardo. Decolonizing epistemologies: latino/a theology and Philospohy. New York: Fordham University Press, 2012. 
Liberation Theology: problematizing the historical projects of democracy...

PAPANIKOLAOU, Aristotle. The mystical as political. Notre Dame: University of Notre Dame Press, 2014.

PETRELLA, Ivan. The future of Liberation Theology: an argument and manifesto. London: SCM Press, 2006.

PETRELLA, Ivan.. Beyond Liberation Theology: a polemic. London: SCM Press, 2008.

SANTOS, Boaventura de Sousa. A difícil democracia. São Paulo: Boitempo, 2016.

SEGUNDO, Juan Luis. El hombre de hoy ante Jesus de Nazaret. v. I. Madrid: Ediciones Cristandad, 1982.

SEGUNDO, Juan Luis. $\mathbf{O}$ dogma que liberta. Sao Paulo: Paulinas, 2000.

SEGUNDO, Juan Luis. The Liberation of Theology. Maryknoll: Orbis Books, 1976.

SUNG, Jung Mo. Cristianismo de libertação: espiritualidade e luta social. São Paulo: Paulus, 2008.

SUNG, Jung Mo. Desire, market and religion. London: SCM Press, 2007.

WOLTERSTORFF, Nicholas. Justice, rights and wrongs. Princeton: Princeton University Press, 2008. 